\title{
Hatékonyság és demokrácia: helyi kormányzási dilemmák a finn periférián
}

\section{Efficiency and democracy: local governance dilemmas on the Finnish periphery}

\author{
NÉMETH SAROLTA, MATTI FRITSCH
}

NÉMETH Sarolta: tudományos főmunkatárs, Kelet-Finnországi Egyetem, Társadalomtudományok és Üzleti Tudományok Kara, Karéliai Kutatóintézet; 80100 Joensuu, Yliopistokatu 2, Finnország; sarolta.nemeth@uef.fi; https://orcid.org/0000-0002-2146-9962

FRITSCH, Matti: tudományos főmunkatárs, Kelet-Finnországi Egyetem, Társadalomtudományok és Üzleti Tudományok Kara, Karéliai Kutatóintézet; 80100 Joensuu, Yliopistokatu 2, Finnország; matti.fritsch@uef.fi; https://orcid.org/0000-0002-6203-5917

KULCSSZAVAK: területi hátrányok; területi igazságosság; zsugorodás; hatékony kormányzás és demokratikus elszámoltathatóság

ABSZTRAKT: A tanulmány azt vizsgálja, hogy a helyi önkormányzásban és döntéshozatalban miképp kapcsolhatók össze a hatékonyság és a demokratikus elszámoltathatóság eltérő céljai és feltételei. Először egy rövid elméleti, szakirodalmi áttekintés alapján jellemezzük a helyi szintű kormányzás különböző elemeit aszerint, hogy azokat a hatékonyság vagy az elszámoltathatóság céljainak rendelik-e alá. Ezt követően egy periferikus helyzetủ finn kisváros, Lieksa esettanulmányán keresztül igyekszünk közelebbről megvizsgálni a hatékonyság és elszámoltathatóság lehetséges összefüggéseit.

Elnéptelenedéssel és forráshiánnyal küzdve, Lieksa 2015-től jelentősen átalakította kormányzási és menedzsmentfolyamatait annak érdekében, hogy hatékonyabb eszközöket nyújthasson fejlesztési céljainak megvalósításához, elsősorban a vállalkozói környezet javításához. Az átalakulás meghatározó eleme a 2015-ben elfogadott településfejlesztési stratégia, mely a gazdasági életképesség (helyi „vitalitás”) célkitűzése mellett a közösség és az állampolgárok helyi döntéshozatalban való részvételének megerősítésére helyezi a hangsúlyt. Tanulmányunk a RELOCAL projekt keretében elvégzett szélesebb körű kutatás eredményein, a településen 2018-2019-ben készített interjúk és fókuszcsoportok anyagának feldolgozásán alapszik. Arra keressük a választ, hogy (1) milyen megfontolások vezérel(het)ik a helyi döntéshozókat a település új fejlesztési stratégiájának hatékony kivitelezése és a demokratikus elszámoltathatóság megvalósítása közötti egyensúlyozásban, illetve, (2) hogy mit érhet el csupán a kormányzási, döntéshozatali folyamatok megújitásával egy periferikus helyzetü, területi hátrányokkal küzdő kisváros önkormányzata.

Az esettanulmány rávilágít arra, hogy az önkormányzás hatékonysága és eredményessége nem választható el annak elszámoltathatóságától és legitimitásától. Megfelelő módon és arányban kombinálva, mechanizmusaik kölcsönösen erösíthetik egymást. A település vezetöinek azonban a különböző helyi érdekcsoportokkal és a település lakóival közös, reflektív tanulási folyamatban kell részt venniük ahhoz, hogy optimális választ találjanak az olyan összetett demográfiai, társadalmi, gazdasági kérdésekre, mint a „zsugorodás” (shrinking), vagy éppen a hatékony kormányzás és a demokratikus elszámoltathatóság közötti egyensúly megteremtése. Azonban, bár innovációk ugyan gyakran kényszerek hatására születnek, külső támogatás hiányában a helyi „öngyógyító” folyamatok eredményei rövid életünek és sérülékenynek bizonyulhatnak.

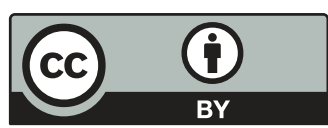


Sarolta NÉMETH: senior researcher, Karelian Institute, Faculty of Social Sciences and Business Studies, University of Eastern Finland; Yliopistokatu 2, FI-80100 Joensuu, Finland; sarolta.nemeth@uef.fi; https:// orcid.org/0000-0002-2146-9962

Matti FRITSCH: senior researcher, Karelian Institute, Faculty of Social Sciences and Business Studies, University of Eastern Finland; Yliopistokatu 2, FI-80100 Joensuu, Finland; matti.fritsch@uef.fi; https:// orcid.org/0000-0002-6203-5917

KEYWORDS: territorial disadvantages; spatial justice; shrinking; effective administration and democratic accountability

ABSTRACT: The study examines how, in local government and decision-making, the different objectives and conditions of efficiency and democratic accountability can be constructively linked. The authors first use a short theoretical-literature review to characterize the different elements of local governance according to whether they are subordinated to the efficiency or accountability goals, and then they use a practical example, the empirical case study of Lieksa, to offer a deeper understanding of their interactions and possible matching in a particular context.

Struggling with depopulation and diminishing resources, in 2015, Lieksa's new leadership decided to significantly restructure their municipal governance and management processes. This was done in order to provide themselves with more effective tools for the achievement of their development goals, most importantly, to improve Lieksa's business environment. A key element of the transformation has been the drafting and implementation of the new municipal strategy, 'Lieksa 2030', adopted in 2015, which emphasizes not only the objective of economic viability or local 'vitality' but also the strengthening of community and citizen participation in local decision making. The study seeks to answer (1) what considerations local decision-makers (should) have when balancing between effectiveness and democratic accountability in the implementation of the municipal development strategy and (2) what a remotely located, territorially disadvantaged small town can achieve in the face of diminishing resources by merely renewing its governance and municipal management processes.

In Lieksa, new practices that promote the transparency of local decision-making processes and the involvement of citizens have increased the place-basedness, acceptance and legitimacy of municipal decisions, such as those related to economic development. However, the political channels of community involvement and public participation were increasingly pushed into the background during the implementation of the strategy and as a result of the pro-business transformation of local government processes. Also, in addition to having increased transparency, few steps have been taken to strengthen the active role of civil society in local government processes.

The case study seeks to draw more general conclusions about 'shrinking' peripheral towns and regions from the considerations regarding the future of Lieksa. For processual change, a certain degree of autonomy at the local level is essential, i.e., that allows making independent decisions that take into account the specifics and interests of the place. Furthermore, Lieksa's example suggests that the efficacy and fruitfulness of development actions and municipal decision-making are inseparable from, and conditioned also by, their accountability and legitimacy. When properly and proportionately combined, their different mechanisms can be complementary and mutually reinforcing. In tackling complex socioeconomic problems such as Lieksa's, it is important to consider potential side effects of, as well as the positive / negative interactions between different interventions that are likely to occur under particular and volatile circumstances. Therefore, local governments and their leaders, in addition to result-oriented problem solving, need to pay more attention to the improvement and renewal of their municipal management and governance processes as required by the uncertainty and changes in external factors. For this, municipal leaders need to engage in continuous and reflective learning with different local stakeholders and residents to find optimal responses to complex socio-economic challenges such as "shrinking" or finding a workable balance between governance tools serving efficiency and democratic participation. However, although innovations are often born under pressure, in the absence of external support, the results of local 'self-healing' processes can prove short-lived and vulnerable in disadvantaged peripheries. 


\section{Bevezetés}

A hatékony kormányzás és döntéshozatal, valamint a demokratikus elszámoltathatóság és legitimáció között húzódó és az igazgatás különböző szintjein megjelenő feszültség problémájára több szerző (lásd Stivers 1994; Behn 1998) már korábban is felhívta a figyelmet. Az elmúlt évtizedben nőtt a téma iránti tudományos érdeklődés. Ez egyrészt az „új közmenedzsment” (new public management, NPM) gyakorlatainak elterjedésével függ össze, másrészt annak kritikájával és azokkal az aggályokkal is, melyek a demokratikus deficit megnyilvánulásaival és következményeivel kapcsolatosak. Kérdés, hogy „a magas szintű termelékenység, hatékonyság, versenyképesség elérése hogyan valósitható meg a részvételi demokrácia alapértékeinek és intézményi mechanizmusainak fenntartásával" (Kaiser, Horváth 2019, 39.).

A közigazgatás reformjának gyakorlati megközelítései, gyakran egy neoliberális menetrend részeként, és az NPM címkéje alá sorolva, a hatékonyságra helyezik a hangsúlyt, azaz a karcsúbb bürokráciára, a magasabb költséghatékonyságra és a közszolgáltatások jobb teljesítményére (lásd Pollitt, Bouckaert 2011). Az ilyen új közigazgatási gyakorlatok az 1980-as években váltak népszerűvé, erősen neoliberális (föleg angolszász gyakorlatban elterjedt) megoldásai között szerepelt a közszolgáltatások magánosítása és piaci értékesítése. Finnországban azonban, akárcsak a többi észak-európai országban, a közszolgáltatások hatékonyabbá és rugalmasabbá tétele (egyelőre) nem járt a jóléti államot lebontó túlzott privatizációval (Montin 2000; Temmes 1998).

A helyi önkormányzatok "fontos kapocsként müködnek a politikai-közigazgatási rendszer és az állampolgárok között" (Vetter, Kersting 2003, 12.), ezért ezeket tekinthetjük az egyik legfontosabb színtérnek, ahol a fent említett ellentmondás a gyakorlatban megjelenik és potenciálisan feloldható. A problémát vizsgálva Vetter és Kersting (2003) megállapítja, hogy a hatékony közigazgatás és döntéshozatal, valamint a demokratikus elszámoltathatóság céljai és megközelítései kölcsönösen támogathatják is egymást, és akár sikerrel kombinálhatók. A kérdés tehát az, hogy miképpen lehet a közszolgáltatások és fejlesztési intézkedések hatékonyságát és az elszámoltathatóságukat, társadalmi elfogadottságukat növelő demokratikus döntéshozatalt helyi szinten összekapcsolni.

Ami a döntések demokratizálását illeti, az elszámoltathatóság felé vezető ún. „hosszú utat” (amelyik az állampolgári szempontokat a képviseleti és választási rendszeren, politikai mechanizmusokon keresztül érvényesíti) ki kell egészítenie egy ún. „rövid útnak”, mely a közvetlen állampolgári kontroll szervezeti formáit és a döntéshozatal folyamatában való konkrétabb részvételét erősíti (World Bank 2004). Az utóbbiak tekintetében érzékelhető az elmúlt tíz-húsz év elméleti és gyakorlatorientált szakirodalmából, hogy megszaporodtak és növekvő figyelmet kapnak a közvetlen demokrácia kísérletei. A demokratikus elszámoltathatóság és legitimitás megerősítésében egyre nagyobb jelentőséget tulajdonítanak a polgárokkal és érdekelt felekkel folytatott folyamatos diskurzus kialakításának. A helyi döntésekben való állampolgá- 
ri és közösségi részvétel az európai többszintü kormányzás és a fenntartható (helyi) fejlődés előfeltételének tekinthető (összhangban az EUSZ 5. cikkének (3) bekezdésében rögzített szubszidiaritás elvével). Részvételi és deliberatív eljárásokat világszerte alkalmaznak - különböző szinteken és formákban (mini nyilvánosságok [minipublics], állampolgári tanács, részvételi költségvetés) - a demokráciákban meglévő legitimációs hiányosságok orvoslására (Oross 2020); a helyi önkormányzat a képviseleti, deliberatív és részvételen alapuló gyakorlatok összekapcsolásának a legideálisabb színtere (Elstub, Escobar 2019).

Hazai szakértők is rámutatnak arra, hogy Európában már a 20. század végére „elsődlegessé vált az igény az önállóságra épülő egyének és csoportok közvetlenebb részvételére és az egyes lokális települési, földrajzi területen belüli közösség megtartására", részben a gyorsuló globalizáció hatására, részben a technokrata, elszemélytelenedő, sok esetben központosított politikai viszonyok miatt (Farkasné Gasparics, Számadó 2015). A téma kutatói viszont felhívják a figyelmet arra is, hogy bár a deliberatív megoldások létrehozhatják a részvétel új tereit, azok nem feltétlenül válnak az intézményi döntéshozatal szerves részévé, és így valódi demokratikus innovációvá (Strandberg, Grönlund 2018; Jonsson, Astrom 2014) - tehát ezeket az új gyakorlatokat össze kell kapcsolni a létező döntési és kormányzási folyamatokkal.

A fentiek tükrében nem nehéz párhuzamot vonni e tendenciák és a NPM „antitéziseként”, de legalábbis korrekciójaként megjelenő „új közkormányzás" (new public governance, NPG) irányába mozduló közigazgatási újítások között. Ugyanis „az NPG-reformok már értéket tulajdonítanak a társadalmi szereplők bevonásának a közpolitikai döntéshozatalba és megvalósításba: jobb minőségü és a részvétel által nagyobb legitimitással bíró döntéseket, valamint a megvalósítás hatékonyságának növekedését várják ettől” (Boda 2020). Elgondolkodhatunk azon is, hogy a társadalmi szereplők bevonása a döntések „minőségét” közvetlenebb módon is támogathatja: az egyre bonyolultabb helyzetek és problémák kezelése kifejezetten megkívánja az állampolgárok és a civil társadalom aktívabb bevonását és szerepük megerősítését a kormányzási folyamatokban (Sørensen, Torfing 2018; Ansell, Gash 2007). Más szóval, a legitimáción felül a civil társadalom ilyen felhatalmazása és mobilizálása segítheti az endogén és helyalapú tudás alkalmazását a döntéshozatali folyamatokban, ami viszont közvetlen módon javíthatja a helyi önkormányzatok működésének hatékonyságát, a döntések és beavatkozások eredményességét. Ezzel kapcsolatban említést érdemel, hogy a döntéshozatal és kormányzás legitimációjának egy, a bemeneti/politikai (input) és kimeneti/teljesítmény (output) legitimáción kívüli köztes, harmadik eleme is megkülönböztethető: az átviteli vagy eljárási (throughput/procedural) legitimitás (Schmidt 2013; Schmidt, Wood 2019). Ennek fó feltételei, mint az elszámoltathatóság, az átláthatóság, a befogadás és a nyitottság olyan kormányzási folyamatokkal és intézményi struktúrákkal teljesíthetők, amelyek elősegíthetik a létező erőforrások jobb hasznosulását, beleértve a tudás és perspektívák szélesebb körének alkalmazását a helyi szinten tapasztalt társadalmi-gazdasági problémák kezelésében is. 
1. táblázat: A helyi közigazgatás és döntéshozatal fő jellemzői az adminisztratív hatékonyság és demokratikus elszámoltathatóság céljainak tükrében

Main features of local administration and decision-making in light of the objectives of administrative efficiency and democratic accountability

\begin{tabular}{|c|c|c|}
\hline & Adminisztratív hatékonyság & Demokratikus elszámoltathatóság \\
\hline Az önkormányzat szerepe & $\begin{array}{l}\text { Szolgáltatások és jólét szolgál- } \\
\text { tatója }\end{array}$ & $\begin{array}{l}\text { A polgárok politikai döntéshoza- } \\
\text { tali folyamatokba való beillesz- } \\
\text { kedésének elősegítője }\end{array}$ \\
\hline $\begin{array}{l}\text { Leginkább megerősített legiti- } \\
\text { mitás }\end{array}$ & $\begin{array}{l}\text { Kimeneti v. teljesítmény- } \\
\text { (output / performance) legiti- } \\
\text { mitás: hatékonyan működő, } \\
\text { eredményes döntések és inter- } \\
\text { venciók által }\end{array}$ & $\begin{array}{l}\text { Bemeneti v. 'politikai' (input / } \\
\text { political) legitimitás: a polgári } \\
\text { igények és érdekcsoportok kép- } \\
\text { viseletét biztosító intézménye- } \\
\text { sült részvételi folyamatok által } \\
\text { Átviteli (throughput / proce- } \\
\text { dural) legitimitás: az input és } \\
\text { output között zajló konstruktív, } \\
\text { inkluzív, interaktív és átlátható } \\
\text { irányítási és érdekegyeztetési } \\
\text { folyamatokkal támogatva }\end{array}$ \\
\hline Az állampolgár szerepe & (Elégedett) 'ügyfél' & $\begin{array}{l}\text { (Döntési folyamatokba bevont) } \\
\text { aktív állampolgár }\end{array}$ \\
\hline Helyi vezetői tulajdonságok & $\begin{array}{l}\text { Professzionális és határozott } \\
\text { 'ügyintéző' (hatékonyság) }\end{array}$ & $\begin{array}{l}\text { Figyelmes bürokrata (reszponzi- } \\
\text { vitás) } \\
\text { Megbízható, tisztességes, pártat- } \\
\text { lan és hiteles }\end{array}$ \\
\hline Helyi vezetési fókusz & Problémamegoldás & Folyamat- 'megoldás' \\
\hline Kormányzási 'stílus' & $\begin{array}{l}\text { 'Üzleties', technokratikus, } \\
\text { a politikától független szakér- } \\
\text { tők helyzetbe hozása; NPM }\end{array}$ & $\begin{array}{l}\text { Részvételi, átlátható, befogadó; } \\
\text { NPG }\end{array}$ \\
\hline
\end{tabular}

Forrás: Stivers 1994, Montin 2000, Vetter, Kersting 2003, Schmidt 2013, Schmidt, Wood 2019, Kaiser, Horváth 2019 és Boda 2020 alapján a szerzók saját szerkesztése

A vonatkozó szakirodalom rövid áttekintése után azonosíthatók a helyi szintü kormányzás és döntéshozatal különböző elemei és jellemzési szempontjai, melyek jelentése és irányultsága annak megfelelően módosul, hogy éppen a hatékonyság vagy az elszámoltathatóság célját hivatottak-e szolgálni (1. táblázat).

A fenti elméleti fejtegetések tükrében, a továbbiakban azt vizsgáljuk, hogy

- a sürgős változás igényével szembesülve, a gyakorlatban milyen megfontolások vezérel(het)ik a helyi döntéshozókat a település új fejlesztési stratégiájának hatékony kivitelezése és a demokratikus elszámoltathatóság 
megvalósítása közötti egyensúly megteremtésében, illetve, hogy

- mit érhet el egy periférikus helyzetű, számos területi hátránnyal küzdő kisváros önkormányzási folyamatainak megújításával?

Jelen értekezés egy, a RELOCAL projekt keretében a szerzők aktív részvételével készült esettanulmányon alapul (Fritsch et al. 2019). Lieksaban 2018-2019 folyamán 26 interjút készítettünk különböző helyi és regionális érdekeltségü közigazgatási, civil és üzleti szereplővel. Az interjúkat és a személyes megfigyeléseket kiegészítettük a stratégiai dokumentumok és a város által publikált online tartalmak vizsgálatával, valamint fókuszcsoportot szerveztünk, melynek keretében egy változatos összetételű (a várost, a vállalkozásokat és a civil társadalmi szektort képviselő), hattagú csoport benyomásait, gondolatait és attitüdjeit vizsgáltuk a település új fejlesztési stratégiájával és jövőbeli kilátásaival kapcsolatban.

\section{Lieksa és adottságai}

\section{Területi hátrányok}

Lieksa elhelyezkedése finn viszonyok között is távoli, elszigetelt; a település saját régióján belül is periferikus helyzetü. Ez a 11000 lakosú kisváros az Észak-Karélia régióban, az orosz határ közelében, a Finn-tóvidék északkeleti szélén található. Kiterjedt területének $\left(4000 \mathrm{~km}^{2}\right)$ közel hatodát a Pielinen-tó, míg a fennmaradó terület túlnyomó részét összefüggő tajgaerdő fedi (átlagos népsűrűsége 3 fö $/ \mathrm{km}^{2}$ ). Jelentősek a településen belüli közlekedési távolságok. Lieksa kompaktabb, központi része a Pielinen északi partján fekszik, míg a településhez tartozó, a finn „nemzeti táj” részét képező Koli Nemzeti Park és turisztikai központ a tó délnyugati partját övezi. A keményebb teleken e településrészek között a jégpáncéllal borított tavon létesített $\mathrm{kb} .7 \mathrm{~km}$ autóúton, az év többi részében azonban csak $60 \mathrm{~km}$ hosszú úton, a tavat megkerülve, esetleg egyórás sétahajózással lehet közlekedni. A régióközponttól, Joensuutól, Lieksa 100 km-re található, ami még a gyorsabb, de csak napi kétszeri összeköttetést biztosító vasúton is kb. másfél óra menetidőt jelent; Helsinkit Joensuuból öt-hat óra vonatozással vagy autózással lehet elérni.

A településszerkezet a városias beépítettségű központ és a szinte lakatlan vidéki térség közötti összes kategóriát magában foglalja. Lieksa kb. 5000 lakosú városközpontja nagyjából olyan, mint egy átlagos finn kisváros: a népsürüség több mint 400 fö $/ \mathrm{km}^{2}$, és a munkahelyek száma meghaladja a kétezret. A központot egy „,ingázó öv” veszi körül, mely sürübben lakott, mint a távoli hátország, de a munkahelyeket itt már az erdészeti, mezőgazdasági vállalkozások adják. A központon és az ingázó övön túl egy nagyon ritkán lakott, erdővel borított terület kezdődik; az erdő azt az erőforrást biztosítja, amelyen a város gazdasága több mint egy évszázada alapul (Halonen et al. 2015; Helminen et al. 2014). 
A település évtizedek óta komoly gondokkal küzd, népessége tartósan fogy és öregszik. A demográfiai hanyatlás hátterében a részben a rossz megközelíthetőségből fakadó, de önmagában is gyenge versenyképességü gazdasági szerkezet és az abból következő, halmozódó társadalmi-gazdasági hátrányok állnak. A 20. század elején a faáru iránti erősödő európai kereslet egy időre jelentősen megnövelte a helyi munkaerő iránti igényt, ami (a háború után állami intézkedésekkel megtámogatva) felgyorsította az erre az erőforrásra támaszkodó vidék népességének növekedését, ami a hatvanas évekre érte el csúcspontját. Lieksanak ekkor több mint 25000 lakosa volt. Alig két évtizeddel később azonban a vidéki periféria strukturális kihívással nézett szembe. Először a fa- és egyéb nyersanyagtermeléssel foglalkozó ágazatok, majd a fafeldolgozó ipar racionalizációja, gépesítése vezetett nagymértékủ migrációhoz a vidéki területekről Finnország (és Svédország) változatosabb gazdasági struktúrájú és magasabb szintű szolgáltatásokat (pl. felsőfokú oktatást) nyújtó városaiba (Rannikko 1999). A következő évtizedekben Lieksa is több, állami beavatkozásokkal támogatott iparági ciklusváltással igyekezett alkalmazkodni a változó körülményekhez (Halonen et al. 2015). A központi politikai beavatkozások azonban nem tudtak javítani az alacsony versenyképességen, nem tudtak fenntartható alapokat teremteni az új iparágak számára. Így a kisváros és térsége nem volt képes megfelelő ütemben alkalmazkodni az egyre gyorsabban változó, egyre inkább globalizálódó piaci viszonyokhoz.

A város az 1960-as évek óta lakosságának felét veszítette el. Az elnéptelenedést eleinte az elsődleges szektorban és a hagyományos ipari ágazatokban csökkenő munkaerőkereslet és a nagyobb városok vonzereje következtében kibontakozó elvándorlás okozta, míg a népességcsökkenést újabban az elöregedésből fakadó természetes fogyás is táplálja. A 64 évesnél idősebb népesség aránya az 1987-es 15\%-ról 2017-re 35\%-ra nőtt. Lieksa ma egy periférikus, zsugorodó és hanyatló kisváros, amely egyszerre küzd tartós munkanélküliséggel és az innovatív vállalkozásokhoz, új gazdasági alapok megteremtéséhez elengedhetetlen képzett, fiatal munkaerő hiányával.

E folyamatok ismeretében érthető, hogy az elmúlt évtizedben Lieksa jelentős pénzügyi nehézségekkel szembesült, a település jövedelme folyamatosan csökkent, míg a (kiváltképp a szociális és egészségügyi ellátáshoz kapcsolódó) terhek és kiadások egyre növekedtek (2. táblázat). A csökkenő népességszám és a nyugdíjasok teljes népességen belüli növekvő aránya mellett a munkanélküliek aránya folyamatosan nőtt, míg 2015-ben elérte a csúcsot (21,5\%), ami akkor az országos rátának több mint duplája volt (Statistics Finland). 
2. táblázat: Lieksa jellemző társadalmi és gazdasági adatai, 2010-2018

Typical social and economic data of Lieksa, 2010-2018

\begin{tabular}{|c|c|c|c|c|c|c|c|c|c|}
\hline & 2010 & 2011 & 2013 & 2012 & 2014 & 2015 & 2016 & 2017 & 2018 \\
\hline a) Népesség (1000) & 12687 & 12585 & 12399 & 12303 & 12117 & 11772 & 11580 & 11297 & 11098 \\
\hline b) Regisztrált munkanél- & 18,00 & 18,80 & 21,40 & 21,40 & 20,60 & 21,50 & 21,20 & 20,50 & 15,60 \\
\hline \multirow{2}{*}{\multicolumn{10}{|c|}{$\begin{array}{l}\text { küliek aránya a munkaké- } \\
\text { pes népességen belül, \% }\end{array}$}} \\
\hline & & & & & & & & & \\
\hline c) Nyugdíjasok aránya a & 38,10 & 38,30 & 38,80 & 39,30 & 40,10 & 41,40 & 41,70 & 42,90 & 43,70 \\
\hline \multicolumn{10}{|l|}{ teljes népességen belül, \% } \\
\hline d) Szociális és egészség- & 3253,3 & 3420,3 & 3820,3 & 4097,3 & 4159,3 & 4388,9 & 4442,9 & 4504,8 & 4513,5 \\
\hline \multicolumn{10}{|l|}{ ügyi szolgáltatások } \\
\hline \multicolumn{10}{|l|}{ müködési költségei, } \\
\hline \multicolumn{10}{|l|}{$€ /$ capita } \\
\hline e) Teljes adóbevétel, M€ & & & & & & 40,80 & 40,63 & 39,12 & 38,90 \\
\hline
\end{tabular}

Forrás: a-d) Statistics Finland, e) Kuntaliitto 2019 alapján saját szerkesztés

\section{Lieksa státusza a finn önkormányzati rendszerben}

Lieksa a 310 finn helyi önkormányzat egyike. A helyi önkormányzatok viszonylag nagy hatáskörrel rendelkeznek, és a finn kormányzati rendszer erős oszlopát jelentik. A jóléti és szociális szolgáltatások széles skálájáért felelnek, tevékenységüket főleg helyi jövedelemadókból finanszírozzák (Haveri, Airaksinen 2007). A helyi önkormányzatok, elsősorban a négyévente zajló helyi választásokon keresztül, a demokratikus képviselet fontos színterei, ám ez a helyi közösségi szint egyúttal fontos identitásképző erőt is jelent. Az önkormányzat legmagasabb döntéshozó szerve a helyi tanács (vagy városi tanács, kunnanvaltuusto), melynek tagjait négy évre választják az arányos képviselet rendszere alapján. A városi tanács tagjai közül választott szűkebb városvezetési testület (kunnanhallitus) felügyeli a tanács által hozott határozatok végrehajtását. A finn helyi kormányzat másik fontos szereplője az önkormányzat vezetője (polgármester), akit a legtöbb esetben a városi tanács nevez ki a városvezetési testület élére, és ő felel az önkormányzati ügyek napi kezeléséért. A politikai és szakmai irányítás egyensúlya tekintetében akadnak ugyan eltérések a finn önkormányzatok között, többnyire azonban, s különösen a kisebb településeken, a rendszer meglehetősen független a politikától: a polgármesterek szakmai alapon dolgoznak, megbízatásuk sem igen kapcsolódik választási ciklusokhoz.

Fontos megjegyezni azt is, hogy a finn helyi önkormányzatoknak részt kell venniük a regionális tanácsok munkájában, ezek irányítják a régiókra kiterjedő tervezést és fejlesztést. Ezen felül az önkormányzatok szabadon társulhatnak, például a szomszédos önkormányzatokkal a költséghatékony szolgáltatások biztosítása érdekében, s ezzel a lehetőséggel leginkább a kisebb települések élnek. Az önkéntes együttműködés gyakori továbbá a szabályozási tervek (területhasz- 
nálat), gazdaságfejlesztési politika, közlekedési és távközlési rendszerek fenntartása, működtetése és a környezetvédelem területén.

Az önkormányzatok költségvetésük csaknem felét szociális és egészségügyi szolgáltatásokra fordítják. A méretgazdaságosság érdekében a közelmúltban erősödtek a reformkezdeményezések, amelyek a költségigényes szociális és egészségügyi feladatok átcsoportosítására irányulnak a helyiről a regionális szintre. Az elmúlt években minden politikai párt foglalkozott a problémával és megfogalmazta saját reformcéljait, a különböző elképzeléseket rendre elemezték és megvitatták, de egyelőre csak néhány térségben, főleg az ország keleti perifériáján (Észak-Karéliában is) került sor - egyelőre többnyire sikeresnek ítélt - ilyen irányú változtatásokra.

Az önkormányzatok meghatározott kritériumok, gazdasági és demográfiai jellemzők alapján kapnak közvetlen támogatást a központi kormányzattól, és szabadon alakíthatják helyi fejlesztéspolitikájukat. Noha az 1990-es évek óta nőtt a finn önkormányzatok döntési kompetenciája és lehetősége az önálló, helyi erőforrásokon alapuló fejlesztésekre, az állami támogatások csökkenése ma már sok esetben korlátozza az elképzelések megvalósításához szükséges pénzügyi rugalmasságot. Ez Finnországban is arra sarkallja a helyi önkormányzatokat, hogy hatékonyabbá tegyék saját erőforrásaik felhasználását, és erősítsék alkalmazkodóképességüket az új kihívásokhoz és lehetőségekhez.

A finn helyi önkormányzatokról szóló törvény közelmúltban történt felülvizsgálatai során megerősödött az állampolgári és közösségi részvétel (osallisuus) mint a helyi kormányzás eszköze. A törvény 5. fejezete („A település lakosságának részvételi joga") a helyi választásokon és népszavazásokon való részvétel jogán túlmenően biztosítja az emberek jogát a lakóhelyüket érintő ügyek befolyásolására. Felkérik az önkormányzatokat, hogy teremtsenek „,változatos és hatékony részvételi lehetőségeket", és többféle módszert javasolnak ennek megvalósítására, ám a részvételi gyakorlatok megszervezését, illetve a konkrét intézkedéseket már nagyrészt az önkormányzati tanácsok belátására és döntésére bízzák (Kuntaliitto 2017).

A pénzügyi megszorítások és strukturális változások együtthatásának következtében Lieksa is a „súlyos költségvetési korlátok és az egyre növekvő számú összetett probléma és kielégítetlen társadalmi igények kereszttüzében" (Sørensen, Torfing 2018,389 .) találta magát. Ez a helyzet a helyi döntéshozókat alapos irányváltoztatásra késztette a település „menedzselésében”. Az átalakulás egyik meghatározó eleme Lieksa 2015-ben elfogadott, a 2030-ig tartó időszakot felölelő településfejlesztési stratégiája, melyben a gazdasági életképesség („vitalitás”), valamint a közösség és az állampolgárok helyi döntéshozatalban való részvételének megerősítése kapott kiemelt hangsúlyt. Az alábbiakban bemutatjuk, hogy a város vezetése milyen intervenciós logika alapján kapcsolta össze a stratégia fó irányvonalait annak érdekében, hogy biztosítsák a vitalitást, azaz a helyi gazdaság megerősödését, illetve növeljék a település népességmegtartó erejét. 


\section{Változás nyomás alatt}

Lieksa pénzügyi és gazdasági nehézségei 2014-2015-re olyan mértékben megnövekedtek, hogy kérdésessé vált a város jövőbeni társadalmi, gazdasági fenntarthatósága és életképessége. A helyi döntéshozók és politikusok aggodalmait csak fokozta a külső nyomás és bizonytalanság, amit a kilátásba helyezett - az önkormányzatok müködésére potenciálisan kiható - közpolitikai reformok okoztak. Ez a helyzet arra ösztönözte Lieksa döntéshozóit, hogy változtassanak a régi önkormányzati berögződéseken, és a változásokra érett légkörben egy fiatal, újításokra nyitott, „progresszív” polgármestert neveztek ki a kisváros élére. Az új polgármester jelentős hatásköröket kapott a helyi politikai vezetéstől, és a következő években fontos szerepet játszott a városirányítás szemléletében és gyakorlataiban végbement változásokban.

Az új településfejlesztési stratégiát a településigazgatás és önkormányzás átalakítására (Lieksa Fejlesztési Stratégiája 2030-ig/Lieksan kaupunki 2015) az új polgármester irányításával dolgozták ki (habár a stratégiamegújítás folyamatát már az elődje megkezdte). A progresszív változás jeleként értékelhetjük, hogy a stra-

1.ábra: Lieksa stratégiai irányvonalainak oksági láncolata

Causal chain of Lieksa's strategic directions

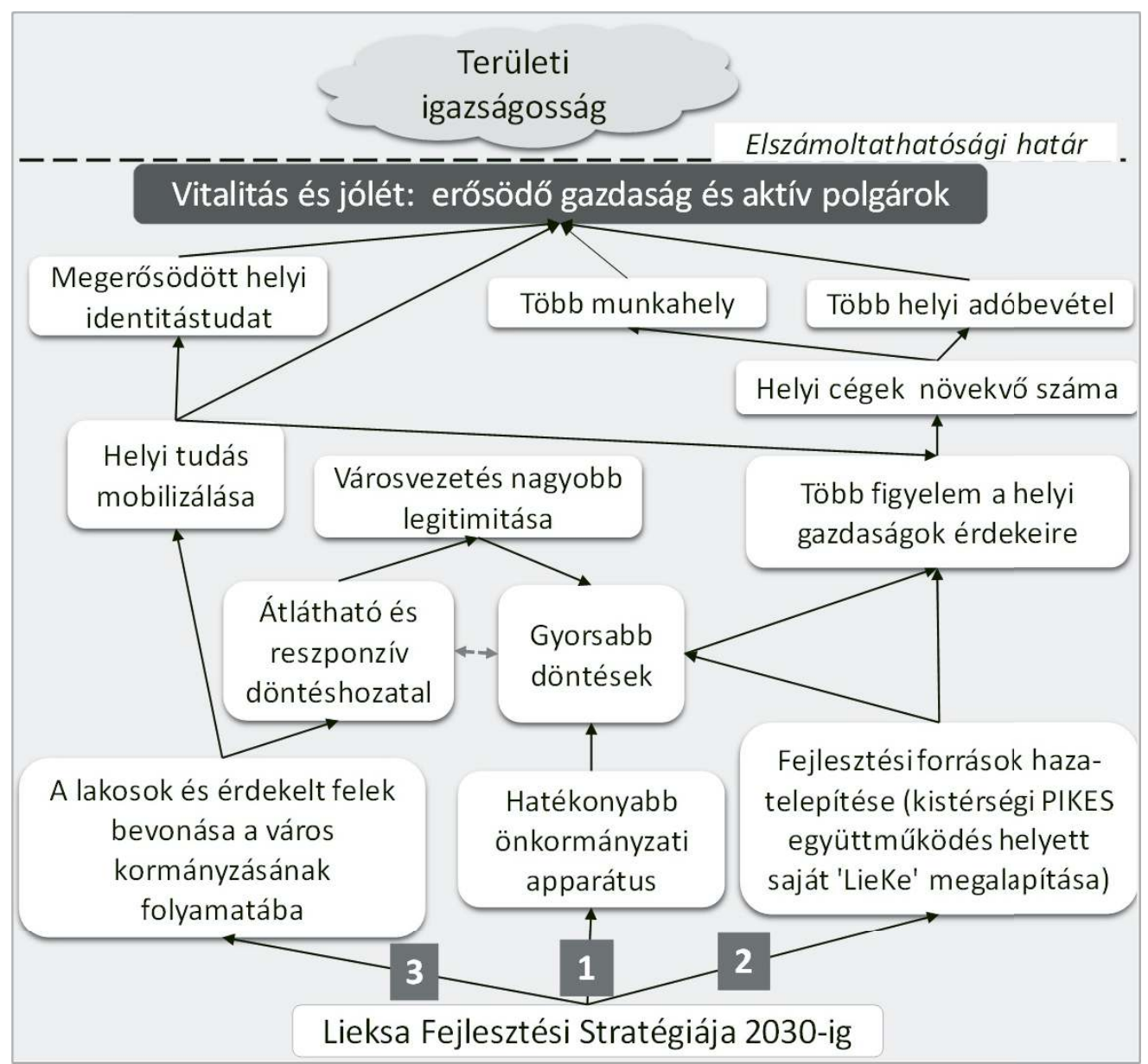

Forrás: a szerzők saját szerkesztése 
tégia irányvonalainak kidolgozásakor, a település történetében először, társadalmi konzultációt és részvételt biztosító tematikus ötletbörzéket, workshopokat szerveztek, amelyeken a Lieksa gazdasági fejlődésében kulcsszerepet játszó gazdasági, intézményi, szolgáltató szektorok és civil szervezetek képviselőivel közösen gondolkodtak, egyeztettek. A Lieksa 2030 stratégia elsődleges célja, hogy javítsa a helyi gazdasági, üzleti környezetet, és a városnak hatékonyabb eszközöket nyújtson saját fejlesztési ambíciói megvalósításához. A stratégia mögött meghúzódó „,területi igazságosság” koncepcióhoz köthető az igény, hogy megőrizzék Lieksa társadalmi és gazdasági életképességét, vitalitását (finnül szó szerint „életerő", elinvoima) a fent elemzett kedvezőtlen folyamatokkal, a többszörös hátrányokkal szemben.

Az 1. ábra a stratégia szövege és az interjúk alapján azonosított három fö beavatkozási irányt mutatja be, melyek oksági láncolatai olykor összeérnek és hatnak is egymásra. A stratégia végső célja a területi hátrányok mérséklése, a helyi gazdasági vitalitásának és vonzerejének erősítése úgy a vállalkozások, mint a helyi közösségek számára.

\section{Első stratégiai irány: hatékonyabb önkormányzati mủködés}

A helyi igazgatás és önkormányzás új megközelítése Lieksaban a településirányítás menedzseri, vállalkozói szemléletének megjelenésében ölt testet. A stratégiában a „vitalitás” célkitűzése azt jelenti, hogy Lieksa vezetése az üzleti szektor fejlesztésére és a gazdaságpolitikára irányítja figyelmét. Ehhez a városvezetésben is a hatékony szakmai előkészítést követő, menedzser szemléletű és gyors döntéshozatal kap hangsúlyt. A városi tanács 2015-től az előkészített szakpolitikai javaslatokat egyre gyakrabban komolyabb nézeteltérések nélkül, minimális vitával, igen gyorsan fogadja el. A pragmatizmus és a törekvés arra, hogy a „dolgok mielőbb elintézésre kerüljenek”, rugalmas és hatékony önkormányzati apparátust eredményezett. Ez kedvező működési környezetet biztosít a helyi vállalkozások és új beruházások számára, ami megteremtheti a Lieksaban élők számára a minőségi szolgáltatások és a jóllét feltételeit. Ahogy a polgármester a vele készített interjú során megfogalmazta: „világos, hogy a gazdasági vitalitás az elsődleges, ha ez nem sikerül, akkor a szociális és egészségügyi ellátás, valamint az oktatási intézmények nem tarthatók fenn".

A szakmaiság, hatékonyság, határozottság nemcsak a város „belügyeinek” kezelésében látható, de megjelenik Lieksa és a környező régió, illetve a szomszédos önkormányzatok közötti kapcsolatokban, a hatékonyabb érdekérvényesítésben is. A Lieksa szociális ügyeiért felelős városvezetési testületi tagot idézve: "(Alapvetöen) az az elképzelés, hogy nem maradt más választás, mint hogy a dolgokat határozottan a saját kezünkbe vegyük, mert az az út, amerre eddig hagytuk, hogy 'sodródjunk', nem vezet sok jóra. (Persze) ez így egy kicsit azért túlzás, mert korábban is gondoltunk Lieksa érdekeire, de azokat most végre érvényesithettük." 


\section{Második stratégiai irány: a fejlesztési források hazatelepitése}

Az érdekérvényesítés jegyében tett konkrét lépés a helyi gazdasági fejlesztésekkel kapcsolatos döntési kompetenciák, kezdeményezések és erőforrások „visszatelepítése" volt Lieksaba a kistérségi együttmüködés szintjéről. Az interjúk rávilágítottak arra, hogy az e döntés mellett szóló alapvető érv szerint az önkormányzatnak meg kell erősítenie Lieksa saját érdekeinek képviseletét, és a település rendelkezésére álló korlátozott forrásokat, a helyi igények és lehetőségek alapos ismeretében, saját lakosságának javára kell felhasználnia.

Lieksa, valamint a szomszédos Nurmes és Valtimo önkormányzatai még 2006-ban megalapították a PIKES (Pielisen Karjalan Kehittämiskeskus Oy) kistérségi gazdaságfejlesztési ügynökséget abból a célból, hogy elősegítsék az ÉszakKarélia északi részét képző Pielinen Karelia kistérség fejlesztését. A működő helyi vállalkozások támogatásán kívül, a PIKES-nek fontos szerep jutott az új befektetések vonzásában, ami kapcsolattartási lehetőséget és első támogatási forrást kínál az olyan vállalkozások számára, amelyek tervezték, hogy a térségbe települnek. Lieksa azonban 2016-ban kilépett ebből a kistérségi együttműködésből, és LieKe (Lieksan Kehitys) néven létrehozta saját gazdaság- és vállalkozásfejlesztési ügynökségét.

Noha a PIKES az egész kistérség javát volt hivatott szolgálni, Lieksa (és Valtimo) úgy értékelte, hogy az ügynökség Nurmes önkormányzatának kedvez, annak ellenére, hogy legnagyobb részvényesként Lieksa várost terhelte a költségek tetemes hányada. A PIKES székhelyét is Nurmesben hozták létre, ami, tekintve a kistérség méretét és természetföldrajzi adottságaiból adódóan „szigetcsoportszerü" települési szerkezetét, viszonylagos előnyt biztosított Nurmesnek és az oda betelepülő cégeknek Lieksaval szemben. Lieksa új vezetése kezdeményező szerepet játszott a PIKES-től való elszakadásban, döntésük pedig összhangban állt az új városi stratégia célkitűzéseivel. Mivel a stratégia egyik alappillére a város vitalitásának javítása (1. prioritási terület), fontosnak tartották, hogy amennyire csak lehetséges, minden ehhez kapcsolódó intézkedés egy közvetlenül a város vezetése által irányított egységhez tartozzon.

Feltehetően e lépések eredményeként, Lieksaban 2015 óta néhány meglévő cég bővítette és fejlesztette termelését, emellett új vállalkozások is indultak, elsősorban a megújuló energia (biogáz) és energiahatékonyság-növelő technológiák, a természetturizmus, valamint a speciális mezőgazdasági termékeken alapuló élelmiszeripar területén. Eddig tehát úgy látszik, hogy sikerült megfordítani a hosszan tartó kedvezőtlen folyamatokat, bár ezek a vállalkozások nem tudnak annyi munkahelyet teremteni, amennyire a fiatalok helyben tartásához Lieksaban szükség lenne (Halonen et al. 2015, 31.). 


\section{Harmadik stratégiai irány: a lakosok és érdekelt felek bevonása a városi kormányzásba}

A helyi igazgatás és önkormányzás új megközelítése a gyorsabb, hatékonyabb döntéshozatal mellett, a ,vitalitás” zászlaja alatt az átláthatóságot és nyitottságot is célul tűzte ki. Mindezek együtt járulnak hozzá a legitimitás, elszámoltathatóság és bizalom megerősítéséhez. Lieksaban ez a törekvés leginkább a részvétel alapvető jogként való elismerését jelenti, vagyis az általános egyetértést abban, hogy a helyi emberi interakciók fontosak a helyi (gazdasági) fejlődés megalapozásában. A részvétel a településfejlesztési stratégia prioritási területeinek egyike, mely szerint "Lieksa lakossága felelősségteljesebb, aktívabb és tudatosabb lesz, növelve az önkormányzati döntések elfogadottságát" (Lieksan kaupunki 2015).

A helyi döntéshozók szemében fontos érték, hogy a polgárok, a civil társadalom számára is hozzáférhetők a döntéshozatallal kapcsolatos információk, és hogy a lieksai vezetőség elérhető és nyitott a kommunikációra. Mi több, ezeket az „adminisztratív hatékonyság” szempontjából is lényeges tényezőknek tekintik. A gyakorlatban ez azt jelenti, hogy a politikai és adminisztratív kommunikáció céljából az interaktív módok és eszközök korábbinál jóval szélesebb spektrumát kezdték alkalmazni. Ezek közé tartoznak például a gyakori elektronikus hírlevelek, a városi tanács üléseiről készült felvételek nyilvánossá tétele a település internetes oldalain, a város vezetésének aktívabb jelenléte a közösségi médiában; de az interaktivitást erősíti az is, hogy az önkormányzati ügyekkel kapcsolatos közvetlen (anonim) visszajelzéseket is begyüjtik elektronikus ürlapok segítségével. Az interjúalanyok általában egyetértettek abban, hogy az önkormányzati vezetőkkel folytatott kommunikáció és interakció jelentős mértékben fejlődött az utóbbi években:

"Véleményem szerint nyilvánvaló, hogy a város kommunikációja átalakult, sokkal nyitottabb, mint korábban, és sokkal gyakoribbak az ilyen irányú akciók. Ha az emberek tudnak a dolgokról, annak a részvételre és kötelezettségvállalásra is hatása van. A döntések már nem 'zárt ajtók mögött' születnek. Amennyiben így definiáljuk a részvételt, akkor úgy gondolom, hogy ez most nagyon jól működik.” (LieKe helyi fejlesztési ügynökség)

A polgármester és a többi helyi vezető egyaránt arra törekszik, hogy személyesen is láthatóak és megközelíthetőek legyenek Lieksa lakói számára, például úgy, hogy részt vesznek sok kisebb helyi eseményen. Feltehetően ez is hozzájárult ahhoz, hogy a lakosság ma már jobban hisz abban, hogy Lieksa pozitív jövő előtt áll. Az egyik interjúalany (a Lieksaban múködő regionális oktatási intézet képviselője) így fogalmazott: "ez véleményem szerint egyfajta motivációt, lelkesedést és hitet ad Lieksa jövőjével kapcsolatban az adófizetók és minden itt élö számára." 


\section{Gondolatkísérlet: amikor a stratégiát szembesítjük a valósággal}

A Lieksa 2030 fejlesztési stratégia három többé-kevésbé elkülöníthető beavatkozási irányra, azaz „intervencióra” épít, melyek különböző okozati láncolatokhoz vezetnek; az 1. ábra foglalta össze ezek megvalósításának eredeti intervenciós logikáját, az események láncolatait és a 2030-ig várt eredményeket. Az érdekelt felekkel folytatott fókuszcsoportos megbeszélések tanulságai, valamint a közeljövőben valószínüsíthetően érvényesülő, elsősorban külső (kontextuális) tényezők hatásának elemzése alapján a 2. ábra már azt mutatja, hogy milyen mértékben változhatnak e láncolatok és kimeneteleik, s hogy mennyire lehet ezekhez alkalmazkodni az elkövetkező évtizedben.

Előreláthatólag számos tényező változtathatja az események menetét, így a fejlesztések várhatóan eltérnek majd egyrészt a kijelölt útvonaltól, másrészt az eredetileg meghatározott hosszú távú céloktól (1. ábra). Nagyon tömören ezek a következőket jelentik:

- A következő évtizedben várhatóan nő Lieksa távolsága a piacoktól és szolgáltatásoktól, ahogy azok egyre inkább a régió központjában, illetve a fövárosban összpontosulnak. A piacokhoz és szolgáltatásokhoz való hozzá-

2. ábra: Lieksa stratégiai irányvonalainak újragondolt oksági láncolata A rethought causal chain of Lieksa's strategic directions

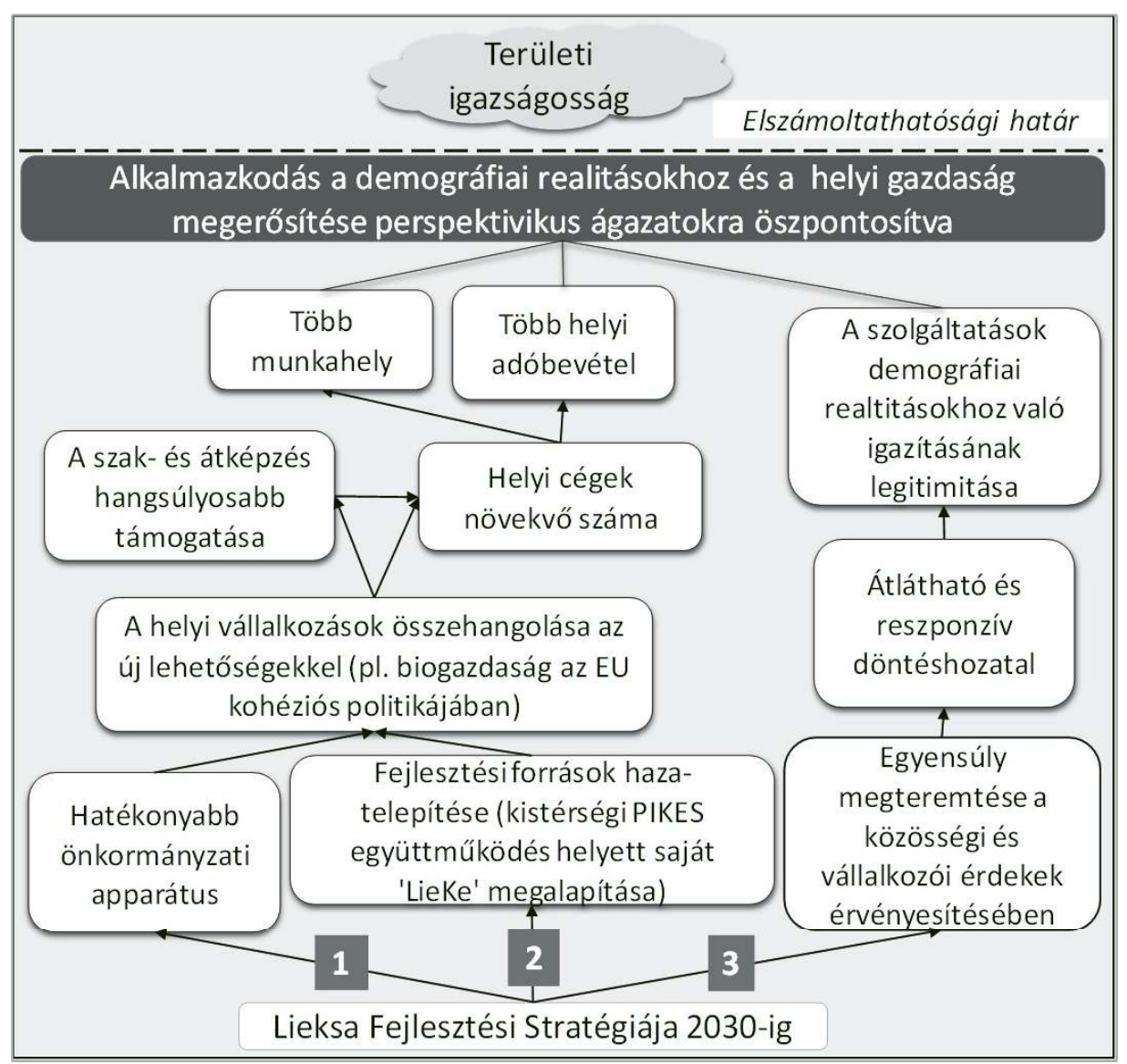

Forrás: Piras et al. 34. ábra $(2020,106$.$) alapján saját szerkesztés$ 
férés egyre nagyobb kihívást jelent majd a növekvő mobilitási költségek és az egyre kevesebb járatszám miatt (pl. várhatóan csökkennek a légiforgalmi kapcsolatok a főváros és a régió között).

- A fejlesztési központoktól távol fekvő vidéki területek önkormányzatai arra számíthatnak, hogy növekszik a munkanélküliség, emellett a népesség elöregedése miatt a jelenleginél is kevesebb munkaerő áll rendelkezésre, s főként a képzett munkaerő hiánya jelent majd hátrányt a már működő és induló helyi vállalkozások számára.

- Az Európai Unió kohéziós politikájával összhangban, a Kohéziós Alapból bővülő, célzott források érkezése várható a társadalmi kihívások megoldására, a biogazdaság fejlesztésére, s e külső források nagy valószínűséggel ösztönző hatással lesznek Lieksa és térsége fejlődésére.

- A termelő ágazatok jelentőségének növekedése várható, annak a már megfigyelhető folyamatnak köszönhetően, hogy nő a kereslet a „zöldebb megoldások", valamint a helyben megtermelt termékek és helyi szolgáltatások iránt.

A „vitalitás” zászlaja alatt Lieksa önkormányzata annak érdekében változtatott korábbi irányítási folyamatain és gyakorlatain, hogy növelje mind a helyi fejlesztésekkel kapcsolatos döntések hatékonyságát, mind azok elszámoltathatóságát, legitimitását. E két ambíció között egyensúlyozni sokszor nem egyszerü. Az interjúk és csoportos beszélgetések rávilágítottak a gyors döntéshozatal egyes nézöpontokat és érdekcsoportokat potenciálisan kizáró természetére: a városi tanács egyre kevesebb vita és egyeztetés után fogadja el a vezető testület által tett különböző, a település társadalmi-gazdasági nehézségeinek megoldására tett javaslatokat. A helyi döntéshozatali folyamatok a pragmatizmus és hatékonyság érdekében függetlenedtek a politikától: "már nincsenek különbözo” politikai pártok, ehelyett egy 'Lieksa pártunk' van”, ahogy a helyi munkanélküliek rehabilitációját támogató non-profit szervezet vezetője fogalmazott, hozzátéve, hogy "ezekben a tisztviselókben bíznak az emberek”, és hogy talán "az emberek túlságosan is lojálisak irányukban”. Az önkormányzat ma a helyi cégeknek, a vállalkozói közösségnek kedvez azzal, hogy döntéseiben a gazdasági szempontok prioritást élveznek a „pusztán” társadalmi megfontolásokkal szemben (mint például a kevésbé domináns érdekcsoportok képviselete és az egyes polgár „aktivizálása”, a politikai döntéshozatali folyamatokba való bekapcsolódásának elősegítése). A jövőben azonban előfordulhat, hogy ez a hozzáállás megakadályozza a harmadik szektor szervezeteinek, és főleg a helyi lakosok egyéni, valódi részvételét és integrációját, aláásva a megszerzett legitimitást és bizalmat.

A fentiek fényében a köztes célok és ok-okozati kapcsolatok több variációját és összefüggését érdemes megfontolni (2. ábra). Az „újragondolt” első oksági láncolat, mely az önkormányzati apparátus hatékonyságát írja le, feltételezhetően inkább ahhoz a kérdéshez kapcsolódik, hogy a helyi vállalkozásokat mennyire sikerül felkészíteni arra, hogy éljenek a kohéziós politika által biztosított finanszírozási lehe- 
tőségekkel. A fejlesztési források hazatelepítésére vonatkozó második oksági láncolatban új oksági kapcsolatokat jelöltünk, amelyben a 2030-ig előreláthatóan növekvő munkanélküliség és munkaerőhiány miatt elengedhetetlen szak- és átképzéshez szükséges befektetések jelennek meg. A harmadik oksági láncolatot, mely a közösség döntéshozatalba való bevonására fókuszál, a közösségi és üzleti, gazdasági érdekek közötti egyensúly felé kell elmozdítani, elsősorban azért, hogy elérhető legyen a demokratikus legitimitás, amely ahhoz szükséges, hogy a szolgáltatások fejlesztése és „méretezése” jobban igazodjon a demográfiai valósághoz.

A várható változások és a hozzájuk való alkalmazkodás oksági láncolatait áttekintve azt mondhatjuk, hogy a „vitalitás” és jóllét eredeti céljai nyilvánvalóan nem érhetőek el 2030-ig. A tágabb demográfiai, gazdasági, társadalmi folyamatok és az uniós fejlesztéspolitika várható alakulásának függvényében a stratégia hosszabb távú céljait némiképp át kell fogalmazni. A céloknak tartalmazniuk kell az alkalmazkodást a tartós népességfogyásból, zsugorodásból (shrinking) fakadó kihívásokhoz. Ugyanakkor reflektálniuk kell azokra a lehetőségekre is, amelyeket az uniós fejlesztési források a gazdasági, társadalmi, környezeti fenntarthatóság és a társadalmi integráció erősítése területén kínálnak.

\section{Következtetések}

Lieksa város vezetése, területi hátrányainak mérséklése érdekében igyekszik megreformálni saját önkormányzási és döntéshozatali folyamatait. 2015-től az önkormányzati apparátus hatékonyabb müködése és a vezetési stílus irányváltása, valamint a fejlesztési források „hazatelepítése” kínál utat Lieksa önkormányzatának egy megfontoltabb, helyalapú (place-based) megközelítés felé, mely elősegítheti, hogy e kisváros jobban ki tudja használni lehetőségeit az új vállalkozások vonzására. A stratégia a gazdasági életképességre fókuszáló célkitűzéseit egy másik irányvonallal is összekapcsolja: a közösség és az állampolgárok részvételének erősítését a helyi döntésekben, főleg azon fiatal és aktív korcsoportok bevonását, akiknek jóllétét (és hajlandóságát a helyben maradásra) kifejezetten fontosnak tartják Lieksa jövője szempontjából.

Már néhány év után látható, hogy Lieksa a korábbinál jobb eséllyel képes olyan új vállalkozásokat a városba vonzani, melyek várhatóan tartósan itt is maradnak. A városvezetés olyan vállalkozásokat lát szívesen, amelyek tevékenysége a helyi természeti erőforrásokra támaszkodik, és így lényegében illeszkedik a térség gazdasági hagyományaihoz és értékeihez. A helyi döntéshozatali folyamatok átláthatóságát és az állampolgárok bevonását segíteni hivatott új gyakorlatok pedig erősítik a - például gazdaságfejlesztéssel kapcsolatos - önkormányzati döntések megalapozottságát és elfogadottságát.

Ennek ellenére már megfigyelhető némi feszültség az önkormányzat gyors és hatékony döntéshozatalra való törekvése és a döntésekbe való beleszólás, be- 
vonódás iránti növekvő társadalmi igény között. A stratégia kidolgozásakor szervezett társadalmi konzultáció még biztosította a helyi tudás beépítését a tervekbe, ahogy az új városvezetés széles körü elfogadottságát (és támogatta annak bemeneti/input legitimitását) is. A közösségi bevonás és lakossági részvétel politikai csatornái azonban fokozatosan háttérbe szorultak a stratégia megvalósítása során azzal, hogy az önkormányzati döntések egyre inkább a vállalkozások érdekeit szolgálják. Ennek eredményeként sérülhetett a városvezetés bemeneti legitimitása. Emellett a transzparencia növelésén túl eddig kevés határozott lépés történt a civil társadalom aktív szerepének megerősítésére a kormányzási folyamatokban. Bár Lieksaban a helyi döntések hatékonysága és átláthatósága bizonyos szempontból erősítette egymást, és látványos eredményeket is eredményezett (a helyi döntések és a kormányzási „stílusváltás” legitimitását a teljesítmény/ output oldalán is támogatva), kritikusabb hangok arra figyelmeztetnek, hogy az önkormányzás nem merülhet ki a technokrata, a vállalkozói, üzleti érdekeket és a hatékonyságot fókuszba helyező menedzseri szemléletben. Ahhoz, hogy a torzulásokat és hatékonyságvesztést időben megelőzzék, a közösségi és egyéni részvételt elősegítő további kísérletekre és újításokra van szükség, amelyek az eljárási/ throughput legitimációt is erősítik.

A célok között a megvalósítás során támadt feszültség mellett a demográfiai helyzet realitásai is megkívánják Lieksa legfőbb fejlesztési céljának újragondolását; a hátrányok leküzdését, tágabban a területi igazságosság elérését nem szolgálhatja pusztán a (gazdasági) növekedés. A szolgáltatások méretoptimalizálásához elengedhetetlen a megfelelő és legitim döntéseket megalapozó társadalmi egyeztetés és támogatottság, melyhez a pozitív jövőkép elővetítése mellett az őszinte kommunikáció is nélkülözhetetlen. A stratégiai beavatkozási láncok kezdeti elemei csak akkor biztosíthatják a kívánt magasabb szintű jóllétet (azaz kiegyensúlyozottabb korszerkezetet, a szolgáltatásokhoz való megfelelő hozzáférést) Lieksa lakói számára, ha a „területi igazságosság” célja elválik a növekedés (például a népesség és munkahelyek számában jelentkező) kényszerétől.

Újra feltesszük a kérdést: mit érhet el egy periferikus helyzetű, számos területi hátránnyal küzdő kisváros az önkormányzás folyamatainak megújításával? Lieksa (és sok más hasonló helyzetű kisváros vagy vidéki térség) számára valószínűleg a vezetői stílusváltás és az önkormányzás döntési, végrehajtási folyamatainak megreformálása maradt az utolsó lehetséges megoldás a területi hátrányokból fakadó forráshiány kezelésére, melyet csak tovább mélyítettek az utóbbi évtized pénzügyi és gazdasági válságai. E finn település példája azt mutatja, hogy elengedhetetlen, hogy a helyi szint rendelkezzen olyan fokú autonómiával, mely lehetővé teszi olyan döntések megszületését, amelyek a hely sajátosságait és érdekeit tartják szem előtt.

A helyi autonómia szükségességén túl azonban nincs egyszerü recept a periferikus helyzetből és strukturális nehézségekből fakadó problémák megoldására. Mint bármely „kezelési protokoll” esetében, itt is fontos figyelembe venni a le- 
hetséges mellékhatásokat, valamint a mindenkori körülmények és a különböző beavatkozások között valószínűsíthető pozitív/negatív kölcsönhatásokat. Ezért az „új közkormányzás” (NPG) szellemében, a helyi önkormányzatoknak és vezetőinek az eredményorientált problémamegoldás mellett több figyelmet kell szentelnie a fejlesztési, döntési és végrehajtási folyamatok összhangjára, valamint azok megújítására, ha a külső tényezők bizonytalansága és változása ezt szükségessé teszi. Ehhez a helyi vezetői elitnek készen kell állnia arra, hogy az állampolgárok és érdekelt felek széles körének bevonásával részt vegyenek reflektív tanulási folyamatokban, melyek segíthetnek választ találni az olyan összetett társadalmigazdasági kihívásokra, mint a „zsugorodás”, és egyidejüleg eleget tenni a hatékony döntéshozatal és a demokratikus elszámoltathatóság elvárásainak. Végül, bár innovációk gyakran születnek nyomás alatt, kényszer hatására, külső támogatás hiányában a helyi „öngyógyító” folyamatok eredményei rövid életűek és sérülékenyek maradhatnak a halmozott hátrányokkal küzdő periférián.

\section{Köszönetnyilvánítás}

Ezt a munkát az Európai Unió Horizon 2020 Kutatási és Innovációs Programja támogatta a 727097 sz. támogatási megállapodás, a RELOCAL (Resituating the local in cohesion and territorial development, 2016-2021) projekt keretében.

This work was supported by the European Union's Horizon 2020 research and innovation programme under grant agreement No. 727097, project RELOCAL (Resituating the local in cohesion and territorial development), $2016-2021$.

\section{Irodalom}

Ansell, C., Gash, A. (2007): Collaborative Governance in Theory and Practice. Journal of Public Administration Research and Theory, 4., 543-571. https://doi.org/10.1093/jopart/mum032

Behn, R. (1998): The new public management paradigm and the search for democratic accountability. International Public Management Journal, 2., 131-164. https://doi.org/10.1016/S1096-7494(99)80088-9

Boda Zs. (2020): Ki dönt? Kormányzási stílusok és közpolitikai változás Magyarországon 2002-2014. Gondolat Kiadó, Budapest

Elstub, S., Escobar, O. (eds.) (2019): Handbook of Democratic Innovation and Governance. Edward Elgar Publishing, Cheltenham UK / Northampton, MA, USA

Farkasné Gasparics E., Számadó R. (2015): A településmenedzsment átalakulása a működési keretek tükrében. Polgári Szemle, 1-3., 195-208. https://polgariszemle.hu/archivum/94-2015-junius-11-evfolyam-1-3-szam/allamtudomany-jogtudomany/656-a-telepuelesmenedzsment-atalakulasa-a-mukodesi-keretek-tuekreben (Letöltés: 2021.10.20.)

Fritsch, M., Hämäläinen, P., Kahila, P., Németh, S. (2019): Case Study Report: Lieksa Development Strategy 2030, Finland (RELOCAL project - Resituating the Local in Cohesion and Territorial Development; Deliverable 6.2) https://relocal.eu/wp-content/uploads/2019/05/11_FI_LieksaCase-Study-Report.pdf (Letöltés: 2021.10.20.)

Halonen, M., Kotilainen, J., Tykkyläinen, M., Vatanen, E. (2015): Industry life cycles of a resource town in Finland - The case of Lieksa. European Countryside, 1., 16-41. https://doi.org/10.1515/ euco-2015-0002 
Haveri, A., Airaksinen, J. (2007): Inter-Municipal Cooperation in Finland: Old Traditions and New Promises. In: Hulst, R., Montfort, A. (eds.): Inter-Municipal Cooperation in Europe. Springer, Dordrecht, 39-67.

Helminen, V., Nurmio, V., Rehunen, A., Ristimäki, M., Oinonen, K., Tiitu, M., Kotavaara, O., Antikainen, H., Rusanen, J. (2014): Kaupunki-maaseutu-alueluokitus. SYKE Reports, A 25/

Jonsson, M. E., Åström, J. (2014): The Challenges for Online Deliberation Research: A Literature Review. International Journal of E-Politics (IJEP), 1., 1-15. https://doi.org/10.4018/ijep.2014010101

Kaiser T., Horváth A. (2019): II. Az állami szerepvállalás területei és tendenciái: a társadalomközpontú és az államközpontú kormányzás. In: Kaiser T. (szerk.): A modern kormányzás koncepcionális és közpolitikai keretei. Hazai és nemzetközi dimenziók. Dialóg Campus Kiadó, Budapest, 33-48.

Kuntaliitto (The Association of Finnish Local and Regional Authorities) (2017): Kuntalaisten osallistuminen. https://www.kuntaliitto.fi/asiantuntijapalvelut/osallistuminen-ja-vuorovaikutus/demokratia-jaosallisuus/kuntalaisten-osallistuminen (Letöltés: 2021.10.20.)

Kuntaliitto (The Association of Finnish Local and Regional Authorities) (2019): Kuntien verotiedot. https://www.kuntaliitto.fi/talous/kuntatalouden-tilastot/kuntien-verotiedot (Letöltés: 2021.10.20.)

Lieksan kaupunki (2015): Lieksan kaupunginstrategia 2030 https://www.lieksa.fi/documents/89419/93385/ Lieksan+kaupungin+strategia_paino.pdf/3f6df6f1-206d-71fc-9452-df10de374c30 (Letöltés: 2021.10.20.)

Montin, S. (2000): Between fragmentation and coordination: The changing role of local government in Sweden. Public Management - an International Journal of Research and Theory, 1., 1-24. https:// doi.org/10.1080/14719030000000001

Oross D. (2020): Versengő demokráciafelfogások, új részvételi lehetőségek? Képviselet, részvétel, deliberáció és demokratikus innovációk. Politikatudományi Szemle, 4., 105-120. https://doi.org/ 10.30718/POLTUD.HU.2020.4.105

Piras, S., Currie, M., Duckett, D., Copus, A., Tobiasz-Lis, P., Dmochowska-Dudek, K. (2020): Report on alternative scenarios for case study regions: Trajectories of spatial justice and actions to achieve it across Europe. (RELOCAL project - Resituating the Local in Cohesion and Territorial Development; Deliverable 8.3) https://relocal.eu/wp-content/uploads/2020/07/RELOCAL_D8.3_020720.pdf (Letöltés: 2021.10.20.)

Pollitt, C., Bouckaert, G. (2011): Public Management Reform - A Comparative Analysis: New Public Management, Governance and the Neo-Weberian State. Oxford University Press, Oxford

Rannikko, P. (1999): Savottojen ja väestökadon Suomi. In: Löytönen, M., Kolbe, L. (eds.): Suomi: Maa, kansa ja kulttuuri. Jyväskylä: Suomen Kirjallisuuden Seuran Toimituksia 753, 211-221.

Schmidt, V. A. (2013): Democracy and Legitimacy in the European Union Revisited: Input, Output and 'Throughput'. Political Studies, 1., 2-22. https://doi.org/10.1111/j.1467-9248.2012.00962.x

Schmidt, V. A., Wood, M. (2019): Conceptualizing throughput legitimacy: Procedural mechanisms of accountability, transparency, inclusiveness and openness in EU governance. Public Administration, 97., 724-740. https://doi.org/10.1111/padm.12615

Sørensen, E., Torfing, J. (2018): The democratizing impact of governance networks: From pluralization, via democratic anchorage, to interactive political leadership. Public Administration, 96., 302-317. https://doi.org/10.1111/padm.12398

Statistics Finland, online database: https://pxnet2.stat.fi/PXWeb/pxweb/en/StatFin/ (Letöltés: 2021.06.10.)

Stivers, C. (1994): The Listening Bureaucrat: Responsiveness in Public Administration. Public Administration Review, 4., 364-9. https://doi.org/10.2307/977384

Strandberg, K., Grönlund, K. (2018): Online Deliberation: - An overview of the central aspects of a growing research field. In: Bächtiger, A, Dryzek, J. S., Mansbridge, J., Warren, M. E. eds.): The Oxford Handbook of Deliberative Democracy. Oxford University Press, Oxford, 365-377.

Temmes, M. (1998): Finland and New Public Management. International Review of Administrative Sciences, 3., 441-456. https://doi.org/10.1177/002085239806400307

Vetter, A., Kersting, N. (2003): Democracy versus efficiency? Comparing local government reforms across Europe. In: Kersting, N., Vetter, A. (eds.): Reforming Local Government in Europe. Urban and Research International 4. VS Verlag für Sozialwissenschaften, Wiesbaden, 11-28.

World Bank (2004): Making services work for poor people (World Development Report 2014). World Bank and Oxford University Press 